\title{
Oxygen consumption and ammonia excretion of the searobin Prionotus punctatus (Scorpaeniformes, Triglidae) at two different temperatures
}

\author{
Vicente Gomes; Phan Van Ngan; Maria José de Arruda Campos Rocha Passos \& \\ Liliana Lucia Christina Forneris \\ Instituto Oceanográfico da Universidade de São Paulo \\ (Caixa Postal 66149, 05315-970 São Paulo, SP, Brasil)
}

- Abstract: Routine oxygen consumption and ammonia excretion were measured at $20^{\circ} \mathrm{C}$ and $25^{\circ} \mathrm{C}$ in the searobin Prionotus punctatus collected in Ubatuba region $\left(22^{\circ} 30^{\prime} \mathrm{S}\right)$, SP, Brazil, in western South Atlantic, to investigate energy expenditure and losses through metabolic processes. Individuals ranging from $1.00 \mathrm{~g}$ to $88.47 \mathrm{~g}$ and from $1.79 \mathrm{~g}$ to $56.50 \mathrm{~g}$ were used in experiments at $20^{\circ} \mathrm{C}$ and $25^{\circ} \mathrm{C}$, respectively. At $20^{\circ} \mathrm{C}$ and $25^{\circ} \mathrm{C}$, the averages of weight-specific oxygen consumption for the weight class of $1.00-10.00 \mathrm{~g}$, common to both temperatures, were $162.46 \pm 39.51 \mu \mathrm{lO}_{2} / \mathrm{g} / \mathrm{h}$ and $200.47 \pm 92.46 \mu \mathrm{OO}_{2} / \mathrm{g} / \mathrm{h}$, respectively; for the weight class of 50.01 $-60.00 \mathrm{~g}$ these values were $112.30 \pm 22.84 \mu \mathrm{IO}_{2} / \mathrm{g} / \mathrm{h}$ and $114.60 \pm 20.36 \mu \mathrm{IO}_{2} / \mathrm{g} / \mathrm{h}$. At $20^{\circ} \mathrm{C}$ and $25^{\circ} \mathrm{C}$, the averages of weight-specific ammonia excretion for the weight class of 1.00 to $10.00 \mathrm{~g}$ were $1.03 \pm 0.37 \mu \mathrm{M} / \mathrm{g} / \mathrm{h}$ and $1.21 \pm 0.65 \mu \mathrm{M} / \mathrm{g} / \mathrm{h}$, respectively; for the weight class of 50.01 $60.00 \mathrm{~g}$ these values were $0.68 \pm 0.13 \mu \mathrm{M} / \mathrm{g} / \mathrm{h}$ and $0.60 \pm 0.22 \mu \mathrm{M} / \mathrm{g} / \mathrm{h}$. The energy budget for the species was calculated at both temperatures using the experimental data and a model for marine teleosts proposed in the literature.

- Resumo: O consumo de oxigênio de rotina e a excreção de amônia de Prionotus punctatus coletados na região de Ubatuba $\left(22^{\circ} 30^{\prime} \mathrm{S}\right)$, SP, Brasil, foram medidos a $20^{\circ} \mathrm{C}$ e $25^{\circ} \mathrm{C}$, para avaliar os gastos e perdas de energia com os processos metabólicos. Foram utilizados indivíduos variando de $1,00 \mathrm{~g}$ a $88,47 \mathrm{~g}$ e de $1,79 \mathrm{~g}$ a $56,50 \mathrm{~g}$, em experimentos a $20^{\circ} \mathrm{C}$ e $25^{\circ} \mathrm{C}$, respectivamente. As médias de consumo específico de oxigênio a $20^{\circ} \mathrm{C}$ e $25^{\circ} \mathrm{C}$ para a classe de peso de $1,00-10,00 \mathrm{~g}$, comum a ambas as temperaturas, foram $162,46 \pm 39,51 \mu \mathrm{lO}_{2} / \mathrm{g} / \mathrm{h}$ e 200,47 $\pm 92,46 \mu \mathrm{lO}_{2} / \mathrm{g} / \mathrm{h}$, respectivamente; para a classe de peso de $50,01-60,00 \mathrm{~g}$ esses valores foram $112,30 \pm 22,84 \mu 1 \mathrm{O}_{2} / \mathrm{g} / \mathrm{h}$ e $114,60 \pm 20,36 \mu 1 \mathrm{O}_{2} / \mathrm{g} / \mathrm{h}$. A $20^{\circ} \mathrm{C}$ e $25^{\circ} \mathrm{C}$, as médias de excreção específica de amônia para a classe de peso de 1,00 a $10,00 \mathrm{~g}$ foram $1,03 \pm 0,37$ e $1,21 \pm 0,65$ $\mu \mathrm{M} / \mathrm{g} / \mathrm{h}$, respectivamente; para a classe de peso de $50,01-60,00 \mathrm{~g}$ esses valores foram $0,68 \pm$ $0,13 \mu \mathrm{M} / \mathrm{g} / \mathrm{h}$ e $0,60 \pm 0,22 \mu \mathrm{M} / \mathrm{g} / \mathrm{h}$. O orçamento energético para a espécie foi calculado para cada temperatura utilizando-se os dados experimentais e modelo proposto na literatura.

- Descriptors: Marine fish, Bioenergetics, Animal metabolism, Energy budget, Excretory products, Oxygen consumption, Prionotus punctatus, Ubatuba, São Paulo, Brazil.

- Descritores: Peixes marinhos, Bioenergética, Metabolismo animal, Orçamento energético, Produtos de excreção, Consumo de oxigênio, Prionotus punctatus, Ubatuba, São Paulo, Brasil. 


\section{Introduction}

The continental shelf of the Ubatuba region (22 $\left.30^{\circ} \mathrm{S}\right)$, SP, Brazil is a subtropical coastal ecosystem with a complex biotic structure and a marked seasonal pattern of water mass circulation that influences the dynamics of living communities. It is also a well populated region exploited by the fishing, tourism and other local industries.

The searobin, Prionotus punctatus (Scorpaeniformes, Triglidae), popularly known in Ubatuba as "cabrinha", is a demersal fish that occurs in the western Atlantic from Jamaica to Argentina, mainly at depths of between 10 and 80 meters. It is a very common species on the Brazilian coast, being found in areas of sand and silt bottoms, in intertidal pools and in the vicinities of estuaries (Figueiredo \& Menezes, 1980). In spite of its being of small economic importance, $P$. punctatus is being increasingly commercialized as frozen meat (Teixeira \& Haimovici, 1989). It is a permanent member of the demersal fish community of the Ubatuba inner shelf, being one of the 22 dominant species of the 171 species recorded in this region (Soares \& Apelbaum, 1994). It seems to use the area during the growing and maturing phases of its life cycle, and is more abundant in warm water masses (Vazzoler* et al., 1988; Rocha \& RossiWongtschowski, 1998). It feeds on slow moving benthic animals, mainly crustacea, indicating its position in the energy chain from detritus to other trophic levels (Soares \& Apelbaum, 1994). Due to its abundance, feeding habits and distribution, the fish is considered to be an important component of the regional food web (Soares \& Apelbaum, op. cit; Rocha \& Rossi-Wongtschowski, op. cit; Soares et al., 1998).

The energy budget of organisms has numerous applications including management, environmental protection, physiological studies, aquaculture, etc., and is one of the best ways to understand their ecology (Karas \& Thoresson, 1992; Lesser et al., 1996; MacIsaac et al., 1997). It is a link between fish physiology and environmental conditions, and when combined with population dynamics, it can lead to system-level estimates of fish production and populational consumption (Brandt \& Hartman, 1993). The bioenergetic investigations of shallow water marine teleosts have received little

(*) Vazzoler, A E. A de M.; Rossi- Wongtschowski, C. L. D. B.; Santoro, E. C. \& Lizama, M. A 1988. Reprodução de teleósteos demersais em um ecossistema costeiro da regiăo de

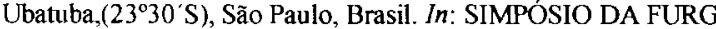
SOBRE PESQUISA PESQUEIRA, I. Rio Grande, 1989. Resumos. Rio Grande, FURG. p.61. attention, despite their importance in these systems (Cockcroft \& DuPreez, 1990). As far as we know, there has been little investigation of this kind in the region of Ubatuba. Aspects of the bioenergetics of Paralonchurus brasiliensis were reported by Phan et al. (1993).

The balanced bioenergetic equation used in the present work is the one proposed by the International Biological Program (IBP) (Ricker, 1968) that describes the general partitioning of energy as: $\mathrm{C}=\mathrm{F}+\mathrm{U}+\mathrm{R}+\mathrm{P}$. It indicates that the energy consumed by a fish (C) is lost as faeces (F), excretion of nitrogenous waste (U) and heat from metabolism (R) or retained for growth (P). Metabolism and nitrogenous excretion are essential for energy budget calculations as they are useful in determining energy needs under different conditions and represent an important percentage of the total balance (DuPreez et al., 1990; Paul, 1997). Nitrogen excretion studies are also important in evaluating the contribution of fish populations to the recycling of nutrients in aquatic environments (Cockcroft \& DuPreez, 1989).

This study is part of a project whose main objective is the quantification of some parameters as an aid in the evaluation of the energy budgets of selected species of Ubatuba's coastal ecosystem, taking into account previous studies on abundance, distribution and ecological importance. For this purpose, the effects of body mass and temperature on routine metabolism and on nitrogen excretion of unfed $P$. punctatus, assessed through oxygen consumption and ammonia excretion repectively, were investigated. These data were also used to estimate the other components of the bioenergetics equation, using the model for marine teleosts proposed by DuPreez et al. (1990), so as to obtain a first approximation of the energy balance for $P$. punctatus. A quantification of the basic energy requirements of the species will contribute to the understanding of certain aspects of its physiological adaptation to the environment and to further comprehension of its ecological role in the energy flow through the coastal ecosystem.

\section{Materials and methods}

Specimens of Prionotus punctatus were collected by 5 minute trawls with a small bottom otter trawl in the "Enseada do Flamengo", Ubatuba, São Paulo State, at depths of between 4 and 11 meters, from the R/B Velliger II. The animals were immediately transferred to plastic boxes with flowing water and brought alive to the coastal laboratory of the Oceanographic Institute, University of São Paulo, 
where they were kept in 500 liter outdoor tanks for at least 15 days for recovery, at air temperature. After this period, the animals were transferred to individual aquariums of 60 liters for acclimation at experimental temperatures $\left(20^{\circ} \mathrm{C} \pm 0.5^{\circ} \mathrm{C}\right.$ or $25^{\circ} \mathrm{C} \pm$ $0.5^{\circ} \mathrm{C}$ ), in the cool room of the coastal laboratory, for 4 to 5 days. The selected temperatures were within the range of environmental temperatures of the region in the period when the fish were caught and also in the range of adjustment with precision of the cool room. Experiments at $20^{\circ} \mathrm{C}$ were held during April/May 1991 and at $25^{\circ} \mathrm{C}$ during October/ November 1991. During the recovery and acclimation periods the animals were fed daily with fresh shrimp meat (Xiphopenaeus kroyeri), the water was artificially aerated, and half of its volume was changed every day. The water used in the tanks, aquaria and also in the experiments was pumped from the sea and passed through a sand filter, followed by a $2 \mu \mathrm{m}$ and $1 \mu \mathrm{m}$ pressure filters. Feeding was suspended 48 hours before the measurements.

Oxygen consumption was determined in closed chamber respirometers made of acrylic tubings sealed at one end and screw capped at the other. Two holes, one large and one small, were made in its wall. The large one ( $15 \mathrm{~mm}$ in diameter) was used to supply running water during acclimation. The small one ( $1 \mathrm{~mm}$ in diameter) was used to allow excess water to escape when the large hole was closed. Volume of the respirometers varied from 500 to 3,500 cubic centimeters to accommodate fish of different sizes. The respirometers were big enough to allow the fish to move freely but not swim actively, characterizing an uncontrolled but minimum activity (routine metabolism). Experimental animals were gently introduced individually into the chambers that were then capped. Running seawater was allowed for six hours, to diminish the stress of the animals due to handling. At the beginning of measurement, the water supply was stopped, the holes in the walls of the respirometers were sealed and the animals were allowed to take up oxygen for a period of 1 to $11 / 2$ hours. This period was established experimentally, in view of the size of the animal in relation to the volume of the respirometer, in order to prevent the oxygen concentration at the end of the experiment from falling to below $70 \%$ of the initial concentration. The respirometers were partly covered to protect fish from excessive light and from the movement inside the laboratory. Samples of water were taken at the beginning and at the end of each experiment for the determination of dissolved oxygen and ammonia concentration. All measurements were made during the daytime and no fish were used twice. Bacterial oxygen consumption was negligible as demonstrated in control experiments under the same conditions. Dissolved oxygen was determined by Winkler's method modified by Fox \& Wingfield (1938) for small volumes of water and ammonia content was determined by the method described by Koroleff (1970). Measurements were made in duplicate. A total of 148 individuals were used for oxygen consumption quantifications, 98 (from $1.00 \mathrm{~g}$ to $88.47 \mathrm{~g}$ wet weight) at $20^{\circ} \mathrm{C}$ and 50 (from $1.79 \mathrm{~g}$ to $56.50 \mathrm{~g}$ wet weight) at $25^{\circ} \mathrm{C}$. Ammonia excretion determinations were made for a total of 207 individuals (148 of them were those used for oxygen consumption quantifications), 157 (from $1.00 \mathrm{~g}$ to $88.47 \mathrm{~g}$ wet weight) at $20^{\circ} \mathrm{C}$ and 50 (from $1.79 \mathrm{~g}$ to $56.50 \mathrm{~g}$ wet weight) at $25^{\circ} \mathrm{C}$.

Data were expressed as individual oxygen consumption $\left(\mu 1 \mathrm{O}_{2} / \mathrm{h}\right)$ and weight-specific consumption $\left(\mu \mathrm{OO}_{2} / \mathrm{g} / \mathrm{h}\right)$. Data of ammonia excretion were also expressed as individual excretion $(\mu \mathrm{M} / \mathrm{h})$ and weight-specific excretion $(\mu \mathrm{M} / \mathrm{g} / \mathrm{h})$. Averages of individual and weight-specific oxygen consumption, and also individual and weight-specific ammonia excretion were calculated for animal grouped in weight class intervals for each temperature.

Individual and weight-specific oxygen consumption and ammonia excretion of the entire data set were analysed as functions of temperature and wet weight of the animals. Data for both sexes were combined because no significant difference between $R$ and $U$ rates of males and females was detected. The relationship between oxygen consumption (R), ammonia excretion (U) and body mass $(\mathrm{W})$ may be described by the logarithmic linear regression equation (Schmidt-Nielsen, 1990): Log ( $R$ or $U)=\log \mathbf{a}+\mathbf{b} \log (W)$, where $\mathbf{a}$ and $\mathbf{b}$ are constants. In this work, regression analysis was applied for data taken as logarithms. The linear regressions obtained were compared by covariance analysis, and the significance of the differences between slopes and elevations were tested by Tukey's test (Zar, 1984). The van't-Hoff temperature coefficient $\left(\mathrm{Q}_{10}\right)$ (Musatov, 1994) for consumption and excretion was calculated from extrapolated average values from regression equations, at both temperatures.

To convert data of oxygen consumption into calories (cal/day), the oxycalorific equivalent of 4.64 $\mathrm{cal} / \mathrm{mlO}_{2}$ (Brett, 1985) was used; for ammonia excretion the equivalent used was of $5.94 \mathrm{cal} / \mathrm{mgN}$ (Elliot \& Davidson, 1975).

To estimate total energy consumption and the other parameters of the bioenergetics equation for different animal sizes at each temperature, the model used was that proposed by DuPreez et al. (1990) for marine teleosts, that considers $\mathrm{C}(100)=\mathrm{F}(10 \pm 6)+$ $\mathrm{U}(4 \pm 1)+\operatorname{Rr}(23 \pm 13)+\operatorname{Rd}(21 \pm 3)+\mathrm{P}(42 \pm 11)$. 
Experimental values of $\operatorname{Rr}$ and $U$ were used to calculate the other components of the equation.

\section{Results}

Individual oxygen consumption obtained at $20^{\circ} \mathrm{C}$ varied from $165.00 \mu \mathrm{l} / \mathrm{h}$ to $10366.20 \mu \mathrm{l} / \mathrm{h}$, while weight-specific oxygen consumption varied from $51.60 \mu \mathrm{l} / \mathrm{g} / \mathrm{h}$ to $324.00 \mu \mathrm{l} / \mathrm{g} / \mathrm{h}$, for animals ranging from $1.00 \mathrm{~g}$ to $88.47 \mathrm{~g}$. At $25^{\circ} \mathrm{C}$, individual consumption was from $406.20 \mu \mathrm{l} / \mathrm{h}$ to $7292.40 \mu \mathrm{l} / \mathrm{h}$ while weight-specific consumption was from 100.20 $\mu \mathrm{l} / \mathrm{g} / \mathrm{h}$ to $534.60 \mu \mathrm{l} / \mathrm{g} / \mathrm{h}$, for animals ranging from
$1.79 \mathrm{~g}$ to $56.50 \mathrm{~g}$. Individual ammonia excretion obtained at $20^{\circ} \mathrm{C}$ was from $0.78 \mu \mathrm{M} / \mathrm{h}$ to 50.44 $\mu \mathrm{M} / \mathrm{h}$, while weight-specific excretion was from $0.10 \mu \mathrm{M} / \mathrm{g} / \mathrm{h}$ to $2.26 \mu \mathrm{M} / \mathrm{g} / \mathrm{h}$, for animals ranging from $1.00 \mathrm{~g}$ to $88.47 \mathrm{~g}$. At $25^{\circ} \mathrm{C}$, individual excretion was of from $3.22 \mu \mathrm{M} / \mathrm{h}$ to $42.99 \mu \mathrm{M} / \mathrm{h}$, while weight-specific excretion was of from 0.37 $\mu \mathrm{M} / \mathrm{g} / \mathrm{h}$ to $3.28 \mu \mathrm{M} / \mathrm{g} / \mathrm{h}$, for animals ranging from $1.79 \mathrm{~g}$ to $56.50 \mathrm{~g}$. To summarize the results and facilitate comparisons, data were calculated as averages for weight classes, as presented in Tables 1 and 2 .

Table 1. Mean values of whole animal (Mcons) and specific (Scons) oxygen consumption, and those for whole animal (Mam) an specific (Sam) ammonia excretion by each weight class of $P$. punctatus, at $20^{\circ} \mathrm{C}$.

\begin{tabular}{cccccccc}
\hline Class & $\begin{array}{c}\text { Weight } \\
(\mathrm{g})\end{array}$ & Ncons & Nam & $\begin{array}{c}\text { Mcons } \\
(\mu \mathrm{IO} / \mathrm{h})\end{array}$ & $\begin{array}{c}\text { Scons } \\
(\mu \mathrm{IO} / \mathrm{g} / \mathrm{h})\end{array}$ & $\begin{array}{c}\text { Mam } \\
(\mu \mathrm{M} / \mathrm{h})\end{array}$ & $\begin{array}{c}\text { Sam } \\
(\mu \mathrm{Mg} / \mathrm{h})\end{array}$ \\
\hline A & $1.00-10.00$ & 46 & 69 & $629.10(467.69)$ & $162.46(39.51)$ & $3.62(2.79)$ & $1.03(0.37)$ \\
B & $10.01-20.00$ & 25 & 43 & $1919.45(560.97)$ & $131.57(40.10)$ & $8.26(4.72)$ & $0.59(0.36)$ \\
C & $20.01-30.00$ & 5 & 15 & $2801.28(1000.29)$ & $110.88(29.58)$ & $11.90(6.07)$ & $0.48(0.23)$ \\
D & $30.01-40.00$ & 3 & 8 & $4722.20(862.94)$ & $137.40(28.48)$ & $21.84(11.09)$ & $0.63(0.31)$ \\
E & $40.01-50.00$ & 5 & 8 & $4685.28(1327.16)$ & $111.72(38.95)$ & $16.99(5.27)$ & $0.39(0.12)$ \\
F & $50.01-60.00$ & 6 & 4 & $6177.10(1186.47)$ & $112.30(22.84)$ & $38.39(7.03)$ & $0.68(0.13)$ \\
G & $60.01-70.00$ & 3 & 3 & $6835.60(1557.93)$ & $100.60(19.40)$ & $33.42(11.17)$ & $0.49(0.15)$ \\
H & $70.01-80.00$ & 3 & 5 & $7945.80(2804.61)$ & $111.60(40.01)$ & $38.30(6.19)$ & $0.48(0.11)$ \\
I & $80.01-90.00$ & 2 & 2 & $9275.10(1543.05)$ & $108.00(16.97)$ & $42.22(7.73)$ & $0.49(0.09)$ \\
\hline
\end{tabular}

Ncons - number of animals for oxygen consumption

Nam - number of animals for ammonia excretion

Standard error in brackets.

Table 2. Mean values for whole animal (Mcons) and specific (Scons) oxygen consumption, and those for whole animal (Mam) and specific (Sam) ammonia excretion by each weight class of P. punctatus, at $25^{\circ} \mathrm{C}$.

\begin{tabular}{ccccccc}
\hline Class & $\begin{array}{c}\text { Weight } \\
(\mathrm{g})\end{array}$ & $\mathbf{N}$ & $\begin{array}{c}\text { Mcons } \\
\left(\mu \mathrm{O}_{2} / \mathrm{h}\right)\end{array}$ & $\begin{array}{c}\text { Scons } \\
\left(\mu \mathrm{O}_{2} / \mathrm{g} / \mathrm{h}\right)\end{array}$ & $\begin{array}{c}\text { Mam } \\
(\mu \mathrm{M} / \mathrm{h})\end{array}$ & $\begin{array}{c}\text { Sam } \\
(\mu \mathrm{M} / \mathrm{g} / \mathrm{h})\end{array}$ \\
\hline A & $1.00-10.00$ & 17 & $1500.78(675.58)$ & $200.47(92.46)$ & $9.03(5.09)$ & $1.21(0.65)$ \\
B & $10.01-20.00$ & 24 & $2033.07(621.77)$ & $152.87(29.13)$ & $9.16(4.27)$ & $0.67(0.20)$ \\
C & $20.01-30.00$ & 4 & $3102.30(135.79)$ & $119.10(15.06)$ & $21.60(8.60)$ & $0.82(0.31)$ \\
D & $30.01-40.00$ & 3 & $4689.40(1045.02)$ & $139.80(23.96)$ & $33.56(8.78)$ & $0.99(0.21)$ \\
F & $50.01-60.00$ & 2 & $6452.10(1188.36)$ & $114.60(20.36)$ & $33.83(12.96)$ & $0.60(0.22)$ \\
\hline
\end{tabular}

$\mathrm{N}$ - number of animals for oxygen consumption and ammonia excretion

Standard error in brackets. 
Individual oxygen consumption and ammonia excretion increased in relation to the wet weight of the animal, at both temperatures (Figs 1, 2, $3,4)$. The equations that express the regression of individual oxygen consumption ( $R$ ) or ammonia excretion $(\mathrm{U})$ as a function of wet weight $(\mathrm{W})$ are: $\log (\mathrm{R})=2.27+0.85 \log (\mathrm{W})$, at $20^{\circ} \mathrm{C}$ (Fig. 1); $\log (R)=2.33+0.84 \log (W)$, at $25^{\circ} \mathrm{C}$ (Fig. 2); $\log (U)=0.08+0.83 \log (W)$, at $20^{\circ} \mathrm{C}$ (Fig. 3); $\log (U)=0.12+0.81 \log (W)$, at $25^{\circ} \mathrm{C}$ (Fig.4).

Weight-specific oxygen consumption and weight-specific ammonia excretion showed a tendency to decrease with wet weight of the animals, at both temperatures. The equations that express the regressions of weight-specific oxygen consumption $\left(R_{\text {esp }}\right)$ or ammonia excretion $\left(U_{\text {esp }}\right)$ as a function of wet weight $(\mathrm{W})$ are:

$\log \left(R_{\text {esp }}\right)=2.27-0.15 \log (W)$, at $20^{\circ} \mathrm{C}$;

$\log \left(R_{\text {esp }}\right)=2.33-0.16 \log (W)$, at $25^{\circ} \mathrm{C}$;

$\log \left(U_{\text {esp }}\right)=0.08-0.17 \log (W)$, at $20^{\circ} \mathrm{C}$;

$\log \left(U_{\text {esp }}\right)=0.17-0.19 \log (W)$, at $25^{\circ} \mathrm{C}$.

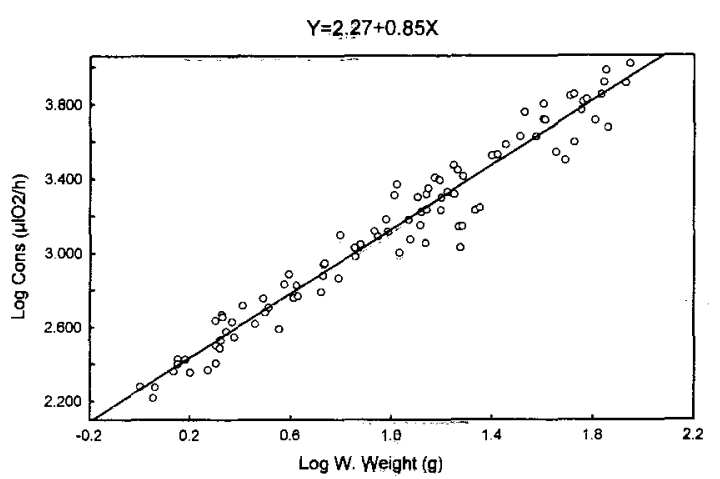

Fig. 1. Oxygen consumption (Cons) in relation to wet weight (W. Weight) of $P$, punctatus, at $20^{\circ} \mathrm{C}$.

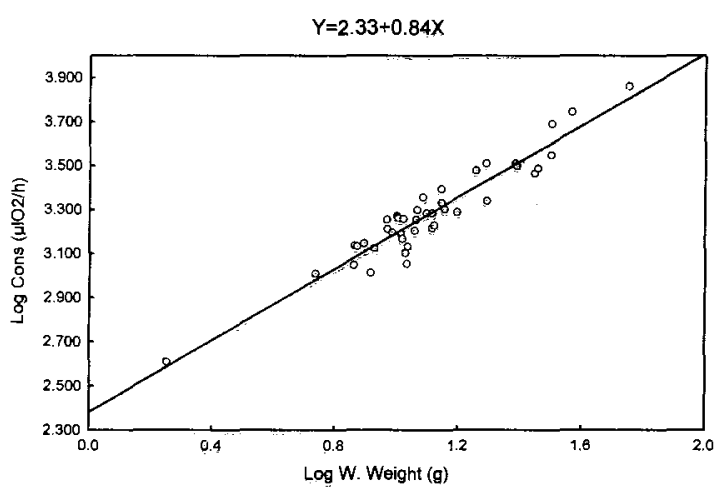

Fig. 2. Oxygen consumption (Cons) in relation to wet weight (W. Weight) of $P$. punctatus, at $25^{\circ} \mathrm{C}$.

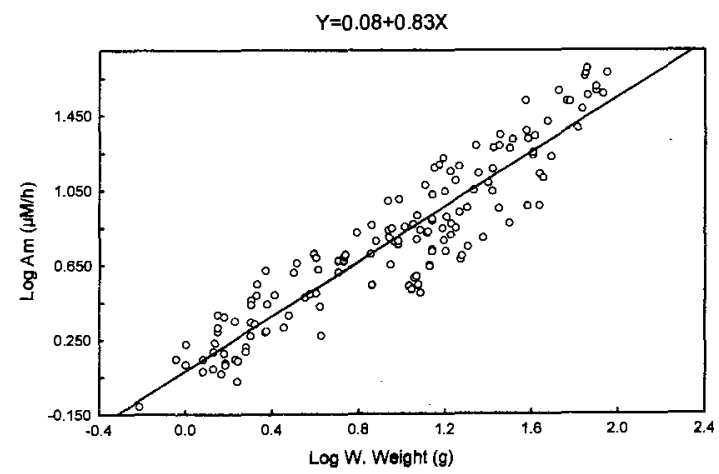

Fig. 3. Ammonia excretion (Am) in relation to wet weight (W. Weight) of $P$. punctatus, at $20^{\circ} \mathrm{C}$.

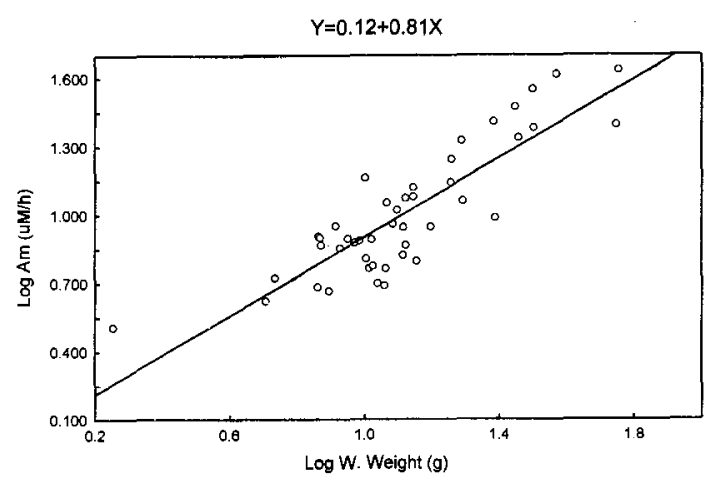

Fig. 4. Ammonia excretion (Am) in relation to wet weight (W. Weight) of $P$. punctatus, at $25^{\circ} \mathrm{C}$.

Both oxygen consumption and ammonia excretion show a tendency to increase with temperature; however, differences of elevation (b) and intercepts (a) between regressions of oxygen consumption and of ammonia excretion at both temperatures were not significant (Tukey's test, $\mathrm{p}=0.05$ ).

Individual oxygen consumption and ammonia excretion obtained from the regression equation for different animal weights were converted into expended calories for daily routine metabolism $(\mathrm{Rr})$ and endogenous ammonia excretion (Uend, obtained from unfed animals). These data were used to estimate the values for the other components of the bioenergetics equation, following DuPreez et al. (1990) as shown in Table 3. At $20^{\circ} \mathrm{C}$, estimated energy necessities of food consumption for maintaining metabolism, excretion and production varied from $650.13 \mathrm{cal} /$ day for a $10 \mathrm{~g}$ fish to 3919.87 $\mathrm{cal} /$ day for an $80 \mathrm{~g}$ one. At $25^{\circ} \mathrm{C}$, estimated values of consumption varied from $797.99 \mathrm{cal} /$ day for a $10 \mathrm{~g}$ fish to $4023.51 \mathrm{cal} /$ day for an $80 \mathrm{~g}$ one.

Table 4 ( $A$ and $B$ ) shows the $Q_{10}$ values for oxygen consumption and ammonia excretion obtained for different fish weights within the experimental range of temperature. They varied from 1.26 to 1.21 for oxygen consumption and from 1.10 to 1.01 for ammonia excretion. 
Table 3. Estimated energy budget for $P$. punctatus, at $20^{\circ} \mathrm{C} \mathrm{(A)} \mathrm{and} 25^{\circ} \mathrm{C} \mathrm{(B).}$

\begin{tabular}{ccccccccc}
\hline $\begin{array}{c}\text { Weight } \\
(\mathrm{g})\end{array}$ & $\begin{array}{c}\mathrm{C}(100 \%) \\
\text { cal/day }\end{array}$ & $\begin{array}{c}\mathrm{Rr}(23 \% \pm 13 \%) \\
\text { cal/day }\end{array}$ & $\begin{array}{c}\mathrm{Rd}(21 \%+3 \%) \\
\text { cal/day }\end{array}$ & $\begin{array}{c}\mathrm{F}(10 \%+6 \%) \\
\text { cal/day }\end{array}$ & $\begin{array}{c}\text { Uend } \\
\text { cal/day }\end{array}$ & $\begin{array}{c}\text { Uexo } \\
\text { cal/day }\end{array}$ & $\begin{array}{c}\mathrm{U}(4 \%+1 \%) \\
\text { cal/day }\end{array}$ & $\begin{array}{c}\mathrm{P}(42 \%+11 \%) \\
\text { cal/day }\end{array}$ \\
\hline 10 (A) & 650.13 & $149.53 \pm 84.52$ & $136.53 \pm 19.50$ & $65.01 \pm 39.01$ & 16.75 & 9.25 & $26.00 \pm 6.50$ & $273.05 \pm 71.51$ \\
80 (A) & 3919.87 & $901.57 \pm 509.58$ & $833.18 \pm 117.59$ & $391.99 \pm 235.19$ & 76.43 & 80.37 & $156.79 \pm 39.20$ & $1646.34 \pm 431.18$ \\
10 (B) & 797.99 & $183.54 \pm 103.73$ & $167.58 \pm 23.93$ & $79.80 \pm 47.88$ & 21.42 & 10.49 & $31.92 \pm 7.98$ & $335.15 \pm 87.78$ \\
80 (B) & 4023.51 & $925.41 \pm 523.06$ & $844.94 \pm 120.71$ & $402.35 \pm 241.41$ & 114.04 & 46.89 & $160.94 \pm 40.24$ & $1689.88 \pm 442.59$ \\
\hline
\end{tabular}

C (consumption); Rr (routine metabolism); Rd (SDA); F (faeces); Uend (endogenous excretion); Uexo (exogenous excretion);

$U$ (excretion); $P$ (production)

Table 4. $\mathrm{Q}_{10}$ values obtained from (A) oxygen consumption (Cons) and (B) ammonia excretion (Am) at $20^{\circ} \mathrm{C}$ and $25^{\circ} \mathrm{C}$, of $P$. punctatus.

(A)

\begin{tabular}{cccc}
\hline $\begin{array}{c}\text { Weight } \\
(\mathrm{g})\end{array}$ & $\begin{array}{c}\text { Cons }\left(20^{\circ} \mathrm{C}\right) \\
\left(\mu \mathrm{O}_{2} / \mathrm{h}\right)\end{array}$ & $\begin{array}{c}\text { Cons }\left(25^{\circ} \mathrm{C}\right) \\
\left(\mu \mathrm{O}_{2} / \mathrm{h}\right)\end{array}$ & $\mathrm{Q}_{10}$ \\
\hline 10 & 1318.26 & 1479.11 & 1.26 \\
20 & 2376.16 & 2647.68 & 1.24 \\
30 & 3353.92 & 3722.05 & 1.23 \\
40 & 4283.03 & 4739.48 & 1.22 \\
50 & 5177.55 & 5716.56 & 1.22 \\
60 & 6045.45 & 6662.65 & 1.21 \\
70 & 6891.81 & 7583.72 & 1.21 \\
80 & 7720.16 & 8483.90 & 1.21 \\
\hline
\end{tabular}

(B)

\begin{tabular}{cccc}
\hline $\begin{array}{c}\text { Weight } \\
(\mathrm{g})\end{array}$ & $\begin{array}{c}\mathrm{Am}\left(20^{\circ} \mathrm{C}\right) \\
(\mu \mathrm{M} /)\end{array}$ & $\begin{array}{c}\mathrm{Am}\left(25^{\circ} \mathrm{C}\right) \\
(\mu \mathrm{M} / \mathrm{h})\end{array}$ & $\mathrm{Q}_{10}$ \\
\hline 10 & 8.13 & 8.51 & 1.10 \\
20 & 14.45 & 14.92 & 1.07 \\
30 & 20.23 & 20.72 & 1.05 \\
40 & 25.69 & 26.16 & 1.04 \\
50 & 30.91 & 31.34 & 1.03 \\
60 & 35.96 & 36.33 & 1.02 \\
70 & 40.87 & 41.17 & 1.01 \\
80 & 45.66 & 45.87 & 1.01 \\
\hline
\end{tabular}

\section{Discussion}

Oxygen consumption is a good way to assess aerobic metabolism and for this reason it is widely used (DuPreez et al., 1986). It is relatively simple to measure and useful to determine energy demand as the heat produced for each unit of oxygen consumed in metabolic processes remains fairly constant, irrespective of whether fat, carbohydrate or protein is being oxidized (Schmidt-Nielsen, 1990). The oxycalorific equivalent used in this work (4.64 $\mathrm{cal} / \mathrm{mlO}_{2}$ ) was proposed by Brett (1985) for teleost fish considering that these animals preferentially used a mixture of protein and fat as substrate. Metabolism represents a large part of the energy budget of organisms and the evaluation of their energy demands has a wide range of applications. This kind of information is currently being used, for instance, in models that predict predation rates and will be useful in the construction of models for the estimation of the carrying capacity of a habitat for species introduced (Paul, 1997).

On the other hand, although the energy lost through ammonia excretion represents only about $4 \%$ of the energy intake of a fish, it is the major form of nitrogen excreted by teleosts. For this reason, it is also an important parameter for the study of the physiological processes of protein utilization, to evaluate the energy losses and energy convertion of these animals. From the ecological point of view, it is important to understand the contribution of a particular species to the recycling of nitrogen in the ecosystem (Meyer \& Schultz, 1985; Cockcroft \& DuPreez, 1989).

Data on oxygen consumption and ammonia excretion of $P$. punctatus is within the range expected for tropical fish (Phan et al., 1993). The relationship between metabolic rates and body mass has been studied in detail since Kleiber (1947) and has been compiled for all sorts of animals, both invertebrates and vertebrates (Schmidt-Nielsen, 1990). The mass exponent b from the general metabolic equation can vary not only interspecifically, but also intraspecifically as a function of endogenous and exogenous factors. Since Winberg (1956) a mass exponent value of between 0.67 and 0.80 has been generally accepted as being common for teleost fish. Cockroft \& DuPreez (1989, 1990) suggested mass exponent values of between 0.67 and 0.90 for oxygen consumption and of between 0.47 to 0.99 for ammonia excretion as a function of wet weight. Ammonia excretion is, in general, considered as more variable intraspecifically than oxygen consumption (Aarset \& Aunaas, 1990). 
It is important to notice, however, that many authors believe that mass exponent found for fish varies widely and that exceptions are not uncommon (Hoss, 1967). Mass exponent values obtained for the searobin in relation to oxygen consumption $(0.85$ and $0.84)$ and to ammonia excretion (0.83 and 0.81$)$ accord with those expected for the majority of teleost fish.

The effect of temperature on metabolic rates was studied in view of to its great effects on almost all physiological processes. It is probably one of the main environmental controlling factors in the metabolism of exothermic animals. Examining the regression lines of oxygen consumption and ammonia excretion obtained for the searobin one can observe that the mass exponent (b) of each parameter is similar at both experimental temperatures. The b values recorded for teleost species are usually temperature independent (DuPreez et al., 1986), reflecting an effect of similar magnitude on animals of different sizes.

Intercept (a) values of regression lines of metabolic rates usually increase significantly with temperature indicating an acceleration of the physiological processes. For the searobin, the observed values of $\mathbf{a}, \mathrm{Q}_{10}$ and the averages of oxygen consumption and ammonia excretion for different classes at different temperatures suggest that metabolism has a common tendency to increase with temperature. Nevertheless, this increase was not significant indicating that the range of temperature tested seems to exert little effect on oxygen consumption or ammonia excretion, in view of the number and size of the animals used in the experiments. These data suggest that temperatures between $20^{\circ}$ and $25^{\circ} \mathrm{C}$ are probably within a zone of metabolic thermal compensation for the species. The lack of metabolic reaction within a certain range of temperature seems to be an expression of optimization of the metabolic processes (Opalinski, 1991). For instance, Brown (1989) studying three species of sculpin (Cottus) found that their routine metabolic rates did not increase significantly between $10^{\circ}$ to $15^{\circ} \mathrm{C}$; increased rapidly between $15^{\circ}$ and $20^{\circ} \mathrm{C}$, followed by little and no significant increase between $20^{\circ}$ and $25^{\circ} \mathrm{C}$. The author concluded that there are possibly two areas of thermal compensation. Similar findings was also obtained for other groups of animals, including crustaceans (Phan et al.,1997; 1998).

It is interesting to note that Soares et al. (1998) found that $P$. punctatus from Ubatuba had a similar daily food intake in summer and winter. The authors considered that this was probably associated with the ecological features of the region and small variation in the water temperature in the sampling period $\left(15.8^{\circ} \mathrm{C}\right.$ on the bed in summer and $19.7^{\circ} \mathrm{C}$ on the bed in winter). In summer, due to the penetration of South Atlantic Central Water (SACW) on the inner shelf, bottom water is colder than during the winter and the water column is highly stratified, with the formation of a characteristic thermocline. The temperature difference between bottom and surface layers may be of more than $10^{\circ} \mathrm{C}$ (Castro Filho et al., 1987). Prionotus punctatus is a bottom feeding fish that is also often captured in surface waters, and must thus be subject to a sharp vertical temperature gradient that should favour adaptive strategies to economize energy. Besides this, as a fish that seems to prefer warm waters, the difference between the experimental temperatures $\left(20^{\circ} \mathrm{C}\right.$ and $\left.25^{\circ} \mathrm{C}\right)$ had little effect on metabolism. Further studies including the lower limits of the temperature range should be undertaken, together with the mechanisms of physiological acclimation, to establish a pattern of response for $P$. punctatus.

Non-controlled factors may affect the variability of the data more intensively than the range of temperature tested. For example, in teleosts, rhythmic activity may be largely responsible for the variation in metabolic rates. In this work, experiments were held at approximately the same time of day. Diel feeding analysis made by Soares $\&$ Apelbaum (1994) and Soares et al. (1998) clearly indicated that $P$. punctatus is a day-time feeder with an afternoon tendency, presenting evidence for a circadian rythmic behaviour. The timing of activities is sometimes described as a familial characteristic of fish (Davis \& Birdsong, 1973 apud Thetmeyer, 1997) and seems to be more widely spread than was supposed in the past (Marques \& Barreto, 1997), thus constituting an open field for investigation.

Few studies have measured all the parameters of the energy budget equation for a fish independently (Xie \& Sun, 1993; Gilman, 1994). In this work, the various parameters of the energy budget were calculated on the basis of differences in the experimental data on oxygen consumption (routine metabolism) and ammonia excretion of nonfed animals (endogenous excretion) using the average energy partitioning proposed by DuPreez et al. (1990) for carnivorous, mainly juvenile, coastal fish. Consequently, the values and their variations only reflect the range of variation measured for oxygen consumption and ammonia excretion. In this sense, it is not possible to evaluate the accuracy of the individual energy budget presented here.

However, the main intention that led to this procedure was to make a first broad approximation of the energy balance for $P$. punctatus using a model for fish of similar characteristics. Data can be considered as tools to generate hypotheses to be 
properly tested to validate assumptions (Xie \& Sun, 1993; Brandt \& Hartman, 1993). Energy consumption values estimated here from metabolism are very similar to laboratory measurements of energy consumption for juvenile croaker (Aristizabal Abud et al., 1992). They are also comparable to the field consumption calculated by Soares et al. (1998) for $P$. punctatus around $80 \mathrm{~g}$ but underestimated in comparison to smaller individuals around $15 \mathrm{~g}$. This may reflect another important constraint of this approximation in which production was considered to be the same for the entire range of the animal's weight. With an adequate approach, using consumption data, growth and mortality rates, egestion losses from future experiments, together with the quantifications of energy demand for routine metabolism and energy losses due to excretion obtained here, an accurate energy budget for the species would be possible.

Data obtained thus far may contribute to an enlargement of the rather limited knowledge on the metabolic requirements of warm coastal marine teleosts and to the modelling of energy budgets and energy flow through coastal marine food webs.

\section{Acknowledgements}

We are grateful to the Oceanographic Institute of São Paulo University (IOUSP), to the Interministerial Commission of Brazilian Sea Resources (SECIRM) for financial support and to the Brazilian Research Council (CNPq) for the reasearch and productivity grants (Procs 301480/91-0 RN and 300299/77-0 RN). We also thank the staff of our laboratory for their help throughout this project, as also the anonymous referees for their careful readings and valuable suggestions.

\section{References}

Aarset, A. V. \& Aunaas, T. 1990. Metabolic responses of the sympagic amphipods Gammarus wilkitzkii and Onisimus glacialis to acute temperature variations. Mar. Biol., 107(3):433438.

Aristizabal Abud, E. O.; Prenski, L. B. \& Daleo, G. R. 1992. Growth and energy budget in juvenile croaker (Micropogonias furnieri (Desmarest 1823)). ICES J. mar. Sci., 49(1):65-68.
Brandt, S. B. \& Hartman, K. J. 1993. Innovative approaches with bioenergetic models: future applications to fish ecology and management. Trans. Amer. Fish. Soc., 122(5):731-735.

Brett, J. R. 1985. Correction in use of oxycalorific equivalent. Can. J. Fish. aquat. Sci., 42(7):13261327.

Brown, L. R. 1989. Temperature preferences and oxygen consumption of three species of sculpin (Cottus) from the Pit River drainage, California. Environ. Biol. Fishes, 26(3):223-236.

Castro Filho, B. M. de; Miranda, L. B. de \& Miyao, S. Y. 1987. Condições hidrográficas na plataforma continental ao largo de Ubatuba: variações sazonais e em média escala. Bolm. Inst. oceanogr., S Paulo, 35(2):135-151.

Cockcroft, A. C. \& DuPreez, H. H. 1989. Nitrogen and energy loss via nonfaecal and faecal excretion in the marine teleost Lithognathus lithognathus. Mar. Biol., 101(3):419-425.

Cockcroft, A. C. \& DuPreez, H. H. 1990. Nitrogen and energy loss in the marine teleost Lithognathus mormyrus (Linnaeus). J. expl mar. Biol. Ecol., 140(3):159-171.

DuPreez, H. H.; McLachlan, A. \& Marais, J. F. K. 1986. Oxygen consumption of a shallow water teleost, the spotted grunter, Pomadasys commersoni (Lacépéde, 1802). Comp. Biochem. Physiol., 84A(1):61-70.

DuPreez, H. H.; McLachlan, A.; Marais, J. F. K. \& Cockcroft, A. C. 1990. Bioenergetics of fishes in a high-energy surf-zone. Mar. Biol., 106(1):1-12.

Elliot, J. M. \& Davidson, W. 1975. Energy equivalents of oxygen consumption in animal energetics. Oecology, 19:195-201.

Figueiredo, J. L. \& Menezes, N. A. 1980. Manual de peixes marinhos do sudeste do Brasil. III. Teleostei (2). São Paulo, MZ-USP. 90p.

Fox, H. M. \& Wingfield, C. A. 1938. A portable apparatus for the determination of oxygen dissolved in a small volume of water. J. expl Biol., 15:437-445.

Gilman, L. S. 1994. An energy budget for northern sand lace, Ammodytes dubius, on Georges Bank, 1977-1986. Fish. Bull., 92(3):647-654. 
Hoss, D. E. 1967. Rates of respiration of estuarine fish. In: ANNUAL CONFERENCE OF THE SOUTHERN ASSOCIATION OF GAME AND FISH COMMISSIONERS, $21^{\text {st }}$. New Orleans, 1967. Proceedings. New Orleans, SAGFC, p. 416-423.

Karas, P. \& Thoresson, G. 1992. An application of a bioenergetic model to Eurasian perch (Perca fluviatilis L.). J. Fish. Biol., 41(2):217230.

Kleiber, M. 1947. Body size and metabolic rate. Physiol. Rev., 27:511-541.

Koroleff, F. 1970. Direct determination of ammonia in natural waters as indophenol blue. Cons. Int. Explor. Mer, (3):122-124.

Lesser, M. P.; Martini, F. H. \& Heiser, J. B. 1996. Ecology of the hagfish, Myxine glutinosa $\mathrm{L}$. in the Gulf of Maine. I. Metabolic rates and energetics. J. expl mar. Biol. Ecol., 208(1/2):215225 .

Maclsaac, P. F.; Golf, G. P. \& Speare, D. J. 1997. Comparison of routine oxygen consumption rates of three species of pleuronectids at three temperatures. J. Appl. Ichthyol., 13(4):17I176.

Marques, N. \& Barreto, L. M. 1997. Cronobiologia: princípios e aplicações. São Paulo, EDUSP. $321 \mathrm{p}$.

Meyer, J. L. \& Schultz, E. T. 1985. Migrating haemulid fishes as a source of nutrients and organic matter on coral reefs. Limnol. Oceanogr., 30(1):I46-156.

Musatov, A. P. 1994. The van't-Hoff temperature coefficient of energy metabolism in lower vertebrates. Hydrobiol. J., 30(5):9699.

Opalinski, W. K. 1991. Respiratory metabolism and metabolic adaptations of Antarctic krill Euphausia superba. Pol. Archs Hydrobiol., 38(2):183-263.

Paul, A. J. 1997. The use of bioenergetic measurements to estimate prey consumption, nutritional status and thermal habitat requirements for marine organisms reared in the sea. Bull. natn. Res. Inst. Aquạcult., Suppl. 3: 5968 .
Phan, V. N.; Gomes, V.; Carvalho, P. S. M. \& Passos, M. J. A. C. R. 1997. Effect of body size, temperature and starvation on oxygen consumption of Antarctic krill Euphausia superba. Rev. bras. oceanogr., 45(1/2):1-10

Phan, V. N.; Gomes, V.; Morais, D. M. \& Passos, M. J. A. C. R. 1993. Estudo bioenergético de animais marinhos costeiros. I. Paralonchurus brasiliensis (Perciformes, Sciaenidae). Publção esp. Inst. oceanogr., S Paulo, (10): 199-21.5.

Phan, V. N.; Gomes, V. \& Passos, M. J. A. C. R. 1998. Routine metabolism and ammonia excretion of the Antarctic amphipod Bovallia gigantea (Pfeffer, 1988) (Crustacea, Amphipoda) in two distinct temperatures. Pesq. antárt. bras., 3(1): 77-85.

Ricker, W. E. 1968. Methods for assessment of fish production in fresh waters. London, IBP. $313 p$.

Rocha, G. R. A. \& Rossi-Wongtschowski, C. L. D. B. 1998. Demersal fish community on the inner shelf of Ubatuba, southeastern Brazil. Rev. bras. oceanogr., 46(2):93-109.

Schmidt-Nielsen, K. 1990. Animal physiology: adaptation and environment. $4^{\text {th }}$ ed. Cambridge/ New York, Cambridge University Press. 602p.

Soares, L. S. H. \& Apelbaum, R. 1994. Atividade alimentar diária da cabrinha Prionotus punctatus (Teleostei, Triglidae) do litoral de Ubatuba, Brasil. Bolm Inst. oceanogr., S Paulo, 42(1/2):85-98.

Soares, L. S. H.; Jarre-Teichmann, A. \& RossiWongtschowski, C. L. D. B. 1998. Field estimates of food consumption of the searobin Prionotus punctatus (Bloch, 1797) on the continental shelf off Ubatuba, southeastern Brazil. Rev. bras. oceanogr., 46(1):45-60.

Teixeira, R. L. \& Haimovici, M. 1989. Distribuição, reprodução e hábitos alimentares de Prionotus punatatus e $P$. nudigula (Pisces: Triglidae) no litoral do Rio Grande do Sul. Atlântica, 11(1):1345 .

Thetmeyer, H. 1997. Diel rhythms of swimming activity and oxygen consumption in Gobiusculus flavescens (Fabricius) and Pomatoschistus minutus (Pallas) (Teleostei: Gobiidae). J. expl mar. Biol. Ecol., 2 I 8(2):187-198. 
Winberg, G. G. 1956. Rate of metabolism and food requirements of fishes. (Transl. from Russian). Fish. Res. Bd Can. Transl. ser., (194):1-253.

Xie, X. J. \& Sun, R. 1993. Pattern of energy allocation in the southern catfish (Silurus meridionalis). J. Fish. Biol., 42(2):197-207.
Zar, J. H. 1984. Biostatistical analysis $2^{\text {nd }}$ ed. Englewood Cliffs, Prentice Hall. 718p.

(Manuscript received 03 November 1998; revised 30 April 1998; accepted 08 November 1999) 